\title{
Simulasi Dinamika Molekuler Senyawa Asam Ferulat dan Turunannya dari Kulit Buah Nanas (Ananas comosus) sebagai Inhibitor Enzim Tirosinase
}

(Molecular dynamics simulation of ferulic acid and its derivatives from pineapple peels (Ananas comosus) as tyrosinase enzyme inhibitors)

\author{
Taufik Muhammad Fakih ${ }^{1 *}$, Hilda Aprilia Wisnuwardhani ${ }^{1}$, Mentari Luthfika Dewi ${ }^{1}$, \\ Dwi Syah Fitra Ramadhan ${ }^{2}$, Aulia Fikri Hidayat ${ }^{1}$ \& Robby Prayitno ${ }^{1}$ \\ ${ }^{1}$ Program Studi Farmasi, Fakultas Matematika dan Ilmu Pengetahuan Alam, Universitas Islam Bandung, \\ Jl. Rangga Gading No. 8, Bandung, Indonesia \\ ${ }^{2}$ Program Studi Farmasi, Universitas Mandala Waluya, Jl. Jend. AH. Nasution Blok G-37, Kendari, Indonesia
}

\begin{abstract}
Tyrosinase enzyme is the key in the melanin pigment formation process. Inhibition of tyrosinase enzyme activity, both competitive and non-competitive is the basis for the developing of skin lightening agents. Ferulic acid is a powerful antioxidant compound and can protect the skin from the adverse effects of UV rays that induce oxidative stress. This study aims to identify the molecular interactions between ferulic acid compounds from pineapple peel (Ananas comosus) and their derivatives against the tyrosinase enzyme using molecular dynamics methods. The molecule compounds are modeled using Quantum ESPRESSO v.6.6. The best model was chosen for an interaction study using MGLTools 1.5.6 with AutoDock 4.2. The best conformation of the molecular docking results was then confirmed for stability by molecular dynamics simulation using Gromacs 2016.3. Based on molecular docking results, iso-ferulic acid compounds had the best affinity, with a binding free energy value of $-25.06 \mathrm{~kJ} / \mathrm{mol}$ and has a bond with zinc metal $(\mathrm{Zn})$ on the active site of the tyrosinase enzyme. Then the compound has good interaction stability based on the graphs of RMSD, RMSF, Rg, SASA, RDF, and H-bond. Therefore, iso-ferulic acid compounds are predicted to be used as candidates for competitive and non-competitive inhibitors of the tyrosinase enzyme.
\end{abstract}

Keywords: antioxidant; pineapple peels; ferulic acid; tyrosinase enzyme; molecular dynamics simulation.

ABSTRAK: Enzim tirosinase merupakan enzim utama pada proses pembentukan pigmen melanin. Penghambatan aktivitas enzim tirosinase secara kompetitif maupun non-kompetitif menjadi kunci utama pengembangan agen pencerah kulit. Asam ferulat merupakan salah satu senyawa antioksidan yang kuat dan mampu melindungi kulit dari dampak buruk sinar UV yang menginduksi stress oksidatif. Penelitian ini bertujuan untuk mengidentifikasi interaksi molekuler antara senyawa asam ferulat dari kulit buah nanas (Ananas comosus) dan turunannya dengan enzim tirosinase menggunakan motode dinamika molekuler. Molekul senyawa uji dimodelkan menggunakan perangkat lunak Quantum ESPRESSO v.6.6. Model terbaik dipilih untuk dilakukan studi interaksi menggunakan perangkat lunak MGLTools 1.5.6 yang dilengkapi dengan AutoDock 4.2. Konformasi terbaik hasil penambatan molekuler kemudian dikonfirmasi stabilitasnya dengan simulasi dinamika molekuler menggunakan perangkat lunak Gromacs 2016.3. Berdasarkan hasil dari penambatan molekuler, senyawa asam iso-ferulat memiliki afinitas yang paling baik, yaitu dengan nilai energi bebas ikatan $-25,06 \mathrm{~kJ} / \mathrm{mol}$ dan memilki ikatan dengan logam seng (Zn) pada sisi aktif enzim tirosinase. Kemudian senyawa tersebut memiki stabilitas interaksi yang baik berdasarkan grafik RMSD, RMSF, Rg, SASA, RDF, dan H-Bond. Dengan demikian, senyawa asam iso-ferulat diprediksi dapat digunakan sebagai kandidat inhibitor kompetitif dan non-kompetitif enzim tirosinase.

Kata kunci: antioksidan; kulit buah nanas; asam ferulat; enzim tirosinase; simulasi dinamika molekuler.

\section{Pendahuluan}

Melanin merupakan pigmen yang bertanggung jawab terhadap penampakan warna kulit manusia. Pada dasarnya, pigmen melanin memiliki fungsi fotoprotektif terhadap dampak buruk paparan sinar UV, akan tetapi akumulasi melanin dalam jumlah berlebih dapat menyebabkan dampak buruk terhadap setiap individu baik secara medis maupun secara estetika [1]. Akumulasi melanin secara berlebih dapat disebabkan oleh banyak faktor, termasuk paparan sinar matahari [2], faktor genetik [3], kondisi kehamilan [4],
Article history

Received: 08 Juni 2021 Accepted: 13 juli 2021 Published: 05 Agust 2021

Access this article

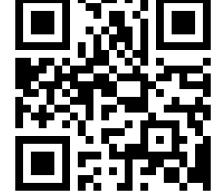


penyakit [5], dan efek samping dari penggunaan obatobatan tertentu [6].

Tirosinase atau dikenal sebagai fenol oksidase adalah enzim kunci yang terlibat dalam proses anabolisme biosintesis melanin (melanogenesis) dalam sel melanosit [7,8]. Enzim ini bertanggung jawab dalam proses katalisasi hampir semua jalur pada reaksi enzimatis melanogenesis, dua diantaranya yaitu pada proses hidroksilasi senyawa monofenol menjadi o-difenol dan oksidasi o-difenol menjadi o-kuinon. Tirosinase akan mengubah tirosin menjadi 3,4-dihidroksifenilalanin (L-DOPA) dan mengoksidasi L-DOPA menjadi dopaquinon yang pada akhir reaksi biosintesis akan diubah menjadi melanin. Penghambatan aktivitas enzim tirosinase menjadi subjek dari berbagai penelitian untuk pengembangan senyawa depigmentasi kulit [9,10].

Senyawa yang digunakan dalam pencegahan hiperpigmentasi kulit pada umumnya bertindak sebagai inhibitor tirosinase secara kompetitif maupun nonkompetitif, yang pada akhirnya diharapkan mampu menghambat sintesis melanin [11]. Di antara agen pencerah kulit dan depigmentasi kulit, senyawa hidroksianisol, arbutin, asam salisilhidroksamat, asam dioat, asam kojat, dan hidrokuinon merupakan senyawa yang paling banyak digunakan dalam industri kosmetik pencerah kulit di seluruh dunia [12-14]. Namun, beberapa kasus melaporakan terkait potensi mutagenisitas, karsinogenitas, dan reaksi merugikan dari beberapa senyawa tersebut, yang pada akhirnya memperburuk kondisi kulit bahkan membahayakan kesehatan pasien pengguna agen pencerah.

Penggunaan hidrokuinon terbukti mengakibatkan sejumlah efek samping, seperti iritasi kulit dan dermatitis pada orang berkulit gelap, lebih jauh bersifat karsinogen $[15,16]$. Oleh karena itu, penggunaan kosmetik yang mengandung hidrokuinon telah dilarang di Uni Eropa dan dikontrol secara ketat di Amerika Serikat oleh Food and Drug Administration (FDA) [17]. Agen topikal lain seperti kortikosteroid, terbukti kurang efektif sebagai pencerah kulit dan dapat menyebabkan efek samping lokal ataupun sistemik setelah penggunaan jangka panjang [18]. Sebaliknya, asam dioat telah digunakan untuk mengobati hiperpigmentasi dengan efektivitas yang baik, namun memiliki efek samping yang sama dengan penggunaan hidrokuinon [19]. Oleh karena itu, diperlukan penelitian lebih lanjut untuk mengembangkan kandidat alternatif agen depigmentasi yang aman berasal dari bahan herbal maupun sintetis.

Asam ferulat merupakan molekul alami yang banyak ditemukan dalam tumbuhan, termasuk dalam kulit buah nanas (Ananas comosus), dan telah dibuktikan dalam penelitian sebelumnya bahwa senyawa ini memiliki berbagai aktivitas farmakologis seperti antioksidan, antiinflamasi, efek antipenuaan dini, kardioprotektif, neuroprotektif, dan antikanker [20-22]. Senyawa bergugus fenol ini diketahui memiliki aktivitas antioksidan yang kuat dan dapat melindungi kulit dari kerusakan oksidatif yang ditimbulkan oleh paparan sinar UV [23]. Penelitian lain menyatakan bahwa struktur molekul asam ferulat mirip dengan struktur molekul tirosin, dalam hal ini merupakan substrat utama pada reaksi enzimatis melanogenesis yang dikatalisis oleh enzim tirosinase. Dengan demikian, asam ferulat memiliki potensi untuk menginhibisi pembentukan melanin melalui penghambatan secara kompetitif terhadap aktivitas enzim tirosinase [24].

Dalam upaya mengembangkan potensi senyawa alami yang memiliki aktivitas inhibitor tirosinase, maka dalam penelitian ini dilakukan studi interaksi molekuler dari beberapa turunan molekul asam ferulat sebagai agen inhibitor tirosinase baik kompetitif maupun nonkompetitif (antioksidan). Melalui penelitian ini diharapkan akan didapatkan struktur molekul acuan sebagai agen depigmentasi kulit.

\section{Metode Penelitian}

\section{Alat dan Bahan}

Bahan yang digunakan dalam penelitian ini adalah struktur kristal makromolekul enzim tirosinase yang membentuk kompleks dengan asam kojat. Makromolekul enzim tersebut diperoleh dari situs web Protein Data Bank (http://www.rcsb.org/pdb) dengan kode PDB 5M8M dan memiliki resolusi 2,65 $\AA$ (Gambar 1) [25]. Molekul senyawa uji yang digunakan dalam penelitian ini adalah asam ferulat dan turunannya, yaitu asam isoferulat, coniferil aldehid, metil ferulat, dan etil ferulat yang memiliki aktivitas terhadap enzim tirosinase serta telah dibuktikan pada penelitian sebelumnya (Gambar 2) [26]. Perangkat lunak yang digunakan pada penelitian ini diantaranya terdapat Sistem Operasi Windows 10, Linux Ubuntu 20.04, MGLTools 1.5.6 yang dilengkapi dengan AutoDock 4.2, ChemDraw Proffesional 16.0, Chem3D 16.0, Quantum ESPRESSO v.6.6, server web Prediction of Activity Spectra for Substances (PASS), server web SWISSADME, BIOVIA Discovery Studio 2020, AnteChamber PYthon Parser interfacE (ACPYPE), Gromacs 2016.3, dan Molecular Mechanics Poisson-Boltrmann Surface Area (MM/ PBSA). Perangkat keras yang digunakan adalah komputer yang dilengkapi fasilitas High Performance Computing (HPC) dengan spesifikasi processor Intel (R) Core i5-8500 CPU @ 4.30GHz (6 CPUs), memory 4096 MB RAM, harddisk 


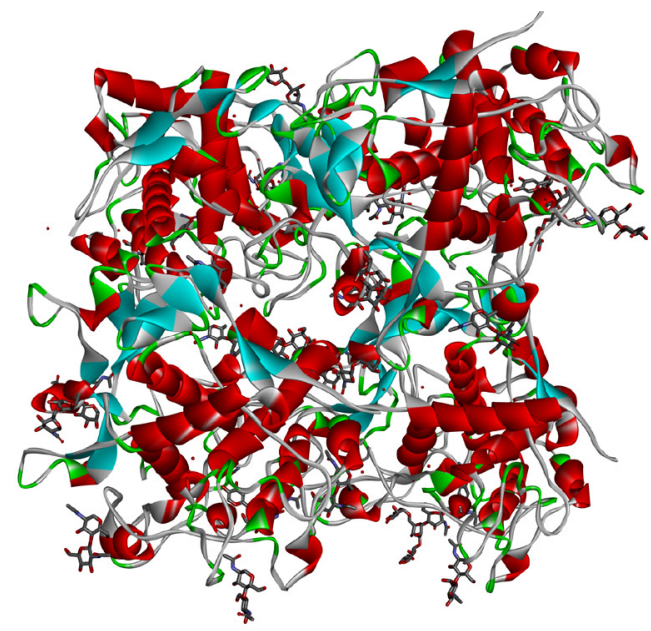

Gambar 1. Struktur kristal makromolekul enzim tirosinase yang telah membentuk kompleks dengan asam kojat

2TB, solid-state drive 120GB, dan VGA Intel HD Graphics NVIDIA GeForce GTX 1080 Ti.

\section{Preparasi Makromolekul Enzim}

Struktur kristal makromolekul enzim tirosinase yang telah diunduh dari situs web Protein Data Bank selanjutnya dipreparasi terlebih dahulu dengan menggunakan perangkat lunak MGLTools 1.5.6 yang dilengkapi dengan AutoDock 4.2. Preparasi makromolekul enzim ini dilakukan dengan menghilangkan molekul air dan ligan alami, kemudian dilanjutkan dengan menambahkan atom hidrogen polar dan menghitung muatan parsial Kollman [27].

\section{Pemodelan Molekul Senyawa Uji}

Senyawa uji yang akan digunakan dalam penelitian ini adalah asam ferulat dan turunannya. Struktur molekul senyawa dilakukan optimasi geometri dengan menggunakan perangkat lunak Quantum ESPRESSO v.6.6 [28]. Kemudian, dipilih metode semi empiris dengan basis set AM1. Struktur yang telah dioptimasi dan dimodifikasi data muatan parsialnya digunakan sebagai input untuk simulasi penambatan molekuler.

\section{Prediksi Aktivitas Biologis Senyawa Uji}

Aktivitas bilogis diprediksi dengan menggunakan server web Prediction of Activity Spectra for Substances (PASS) yang dapat diakses melalui situs web http://www. way2drug.com/PASSOnline/predict.php [29]. Prediksi PASS dilakukan dengan menggunakan data SMILES senyawa uji, kemudian spektrum aktivitasnya diprediksi berdasarkan nilai probable activity $(\mathrm{Pa})$ dan probable inactivity (Pi). Probabilitas Pa and Pi bervariasi antara 0,000 hingga 1,000. Prediksi PASS diinterpretasikan dalam rentang<smiles>COc1cc(/C=C/C(=O)O)ccc1O</smiles>

Asam Ferulat<smiles>COC(=O)/C=C/c1ccc2c(c1)O[CH-]O2</smiles>

Metil Ferulat<smiles>COc1ccc(/C=C/C(=O)O)cc1O</smiles>

Asam iso-Ferulat<smiles>CCOC(=O)/C=C/c1ccc2c(c1)O[CH]O2</smiles>

Etil Ferulat

Gambar 2. Struktur molekul asam ferulat dan turunannya 
Tabel 1. Energi total hasil optimasi geometri molekul senyawa uji

\begin{tabular}{cc}
\hline Senyawa Uji & Energi Total (au) \\
\hline Asam ferulat & $-0,20599920$ \\
Asam iso-ferulat & $-0,20982568$ \\
Coniferil aldehid & $-0,11831105$ \\
Metil ferulat & $-0,19527734$ \\
Etil ferulat & $-0,20434297$ \\
\hline
\end{tabular}

yang fleksibel, yaitu: (i) Nilai $\mathrm{Pa}>$ Pi dianggap memiliki kemungkinan aktif; (ii) jika $\mathrm{Pa}>0,7$ peluang aktif secara eksperimen tinggi; (iii) jika $\mathrm{Pa}>0,5$ tapi lebih kecil dari 0,7 peluang aktif secara eksperimental ada, akan tetapi senyawanya mungkin berbeda dengan agen farmasi yang sudah diketahui; (iv) jika $\mathrm{Pa}<0,5$ peluang untuk menemukan aktivitas secara eksperimental rendah, namun peluang untuk menemukan entitas kimia baru tinggi $[30,31]$.

\section{Identifikasi Sisi Aktif Makromolekul Enzim}

Makromolekul enzim yang telah dipreparasi kemudian diidentifikasi, dievaluasi, dan dieksplorasi bagian sisi aktif pengikatan yang berperan terhadap aktivitas biologis dengan menggunakan perangkat lunak BIOVIA Discovery Studio 2020 [32]. Molekul asam kojat yang berperan sebagai ligan alami dari makromolekul enzim tirosinase digunakan untuk mengidentifikasi dan mengevaluasi area sisi aktif dari makromolekul enzim tersebut.

\section{Validasi Metode Penambatan Molekuler}

Sebelum dilakukan penambatan molekuler antara molekul senyawa asam ferulat dan turunannya dengan enzim tirosinase, terlebih dahulu harus dilakukan validasi metode penambatan molekuler dengan menggunakan perangkat lunak MGLTools 1.5.6 yang dilengkapi dengan AutoDock 4.2 untuk menentukan beberapa parameter yang akan digunakan dalam simulasi penambatan molekuler. Validasi metode terhadap parameter penambatan molekuler ini dilakukan dengan menggunakan metode re-docking. Pada proses re-docking diamati nilai Root Mean Square Deviation (RMSD) yang dibatasi dengan maksimal radius $2 \AA$ [33].

\section{Simulasi Penambatan Molekuler}

Simulasi penambatan molekuler dilakukan dengan menggunakan perangkat lunak MGLTools 1.5.6 yang dilengkapi dengan AutoDock 4.2 untuk mengamati dan mengidentifikasi afinitas dan interaksi yang terjadi antara makromolekul enzim tirosinase dengan molekul asam ferulat dan turunannya. Jarak antara bagian permukaan makromolekul enzim dan molekul senyawa uji dibatasi dengan batas radius maksimum $0,375 \AA$. Semua simulasi dilakukan menggunakan ukuran grid box 64 × 60 × 60,

Tabel 2. Prediksi aktivitas biologis molekul senyawa uji

\begin{tabular}{cccc}
\hline Senyawa Uji & Aktivitas Biologis & Pa & Pi \\
\hline Asam ferulat & Melanin inhibitor & 0,445 & 0,004 \\
& Tyrosine 3 hydroxylase inhibitor & 0,450 & 0,008 \\
Asam iso-ferulat & Melanin inhibitor & 0,445 & 0,004 \\
& Tyrosine 3 hydroxylase inhibitor & 0,008 \\
Coniferil aldehid & Melanin inhibitor & 0,274 & 0,015 \\
Metil ferulat & Tyrosine 3 hydroxylase inhibitor & 0,200 & 0,199 \\
& Melanin inhibitor & 0,512 & 0,003 \\
Etil ferulat & Tyrosine 3 hydroxylase inhibitor & 0,371 & 0,021 \\
& Melanin inhibitor & 0,496 & 0,003 \\
& Tyrosine 3 hydroxylase inhibitor & 0,490 & 0,005
\end{tabular}




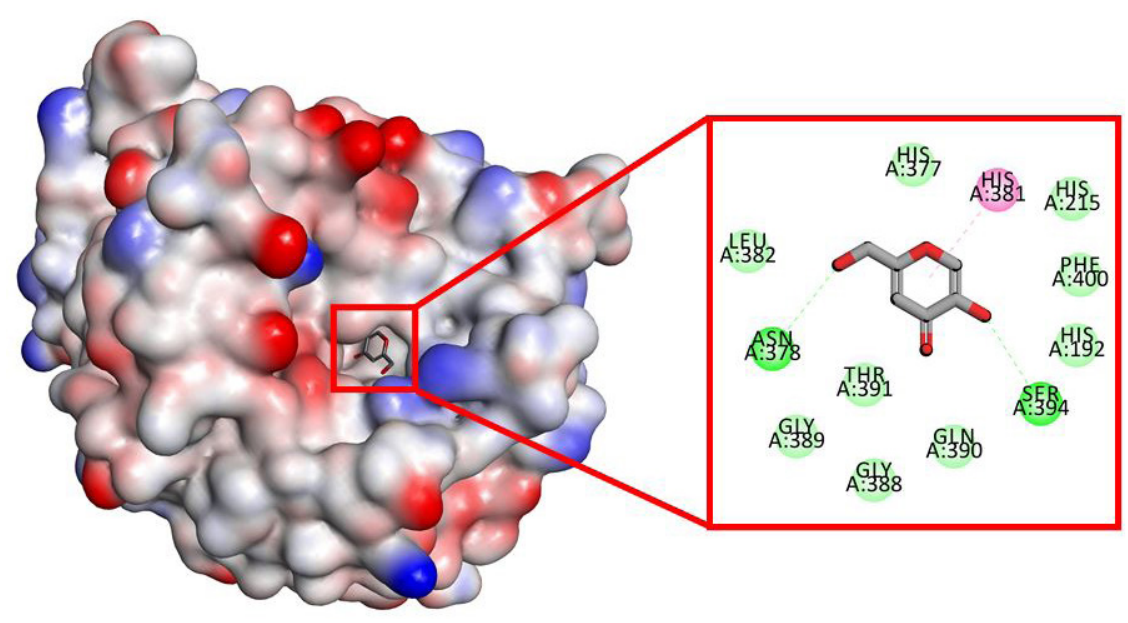

Gambar 3. Bagian sisi aktif pengikatan makromolekul enzim tirosinase

selanjutnya digunakan metode Lamarckian Genetic Algorithm dengan 100 konformasi [34].

\section{Analisis Hasil Simulasi Penambatan Molekuler}

Dari hasil dari penambatan molekuler kemudian diidentifikasi dan dievaluasi interaksi molekuler yang terjadi antara makromolekul enzim tirosinase dengan molekul senyawa uji berdasarkan nilai energi bebas ikatan [35]. Residu asam amino yang berperan dalam interaksi molekuler yang terbentuk diamati dengan menggunakan perangkat lunak BIOVIA Discovery Studio 2020.

Prediksi Profil Adsorpsi, Distribusi, Metabolisme, dan Ekskresi (ADME)

Prediksi profil adsorpsi, distribusi, metabolisme, dan ekskresi (ADME) dilakukan terhadap keseluruhan senyawa uji yang digunakan. Prediksi ADME dapat digunakan untuk menentukan bentuk sediaan yang cocok untuk diformulasikan kedepannya, apakah obat cocok dijadikan sediaan oral atau tidak. Kemudian, prediksi profil ADME ini dilakukan dengan menggunakan server web SWISSADME (https://www.swissadme.ch) yang memungkinkan pengguna untuk menggambar atau memasukkan data senyawa uji dan menyediakan parameter seperti lipofilisitas, kelarutan dalam air, serta aturan kemiripan obat oral [36].

Simulasi Dinamika Molekuler

Simulasi dinamika molekuler dilakukan dengan menggunakan perangkat lunak Gromacs 2016.3 dengan medan gaya AMBER99SB-ILDN [37]. Parameterisasi asam ferulat dan turunannya dilakukan dengan menggunakan AnteChamber PYthon Parser interfacE (ACPYPE) [38]. Gaya elektrostatik ditentukan dengan menggunakan metode Particle Mesh Ewald. Netralisasi sistem dilakukan dengan menambahkan ion natrium $(\mathrm{Na}+)$ dan klorida (Cl-). Tahapan solvasi dilakukan dengan menggunakan model air TIP3P. Proses persiapan simulasi ini meliputi tahap minimisasi, pemanasan hingga $310{ }^{\circ} \mathrm{K}$, kesetimbangan suhu, kesetimbangan tekanan, dan dilanjutkan dengan proses produksi selama 200ns. Pada akhir simulasi dilakukan analisis Root Mean Square Deviation (RMSD), Root Mean Square Fluktuation (RMSF), Radius of Gyration (Rg), Solvent-Accessible Surface Area (SASA), Radial Distribution Function (RDF), dan analisis ikatan hidrogen (H-Bond).

\section{Perhitungan Molecular Mechanics Poisson- Boltzmann Surface Area (MM/PBSA)}

Perhitungan energi bebas ikatan dengen menggunakan

Tabel 3. Energi bebas ikatan hasil simulasi penambatan molekuler

\begin{tabular}{cc}
\hline Senyawa Uji & Energi Bebas lkatan (kJ/mol) \\
\hline Asam ferulat & $-21,38$ \\
Asam iso-ferulat & $-25,06$ \\
Coniferil aldehid & $-20,59$ \\
Metil ferulat & $-21,88$ \\
Etil ferulat & $-19,87$ \\
\hline
\end{tabular}


metode Molecular Mechanics Poisson-Boltzmann Surface Area (MM/PBSA) yang telah terintegrasi dengan perangkat lunak Gromacs 2016.3 [39]. Menurut metode MM-PBSA ini energi bebas ikatan kompleks adalah selisih antara energi bebas kompleks dan reseptor tak terikat dan ligan bebas. Energi desolvasi polar dihitung berdasarkan persamaan Poisson-Boltrmann dengan ukuran grid 0,5. Konstanta dielektrik pelarut diatur pada 80 untuk mewakili air sebagai pelarut. Perhitungan kontribusi nonpolar dilakukan dengan menghitung luas permukaan yang diakses oleh pelarut dengan radius pelarut 1,4. Perhitungan energi bebas ikatan ligan-reseptor ditunjukkan berdasarkan hasil simulasi dinamika molekuler kompleks.

\section{Hasil dan Diskusi}

Kandidat agen depigmentasi yang efekti dengan efek samping minimum saat ini menjadi suatu kebutuhan penting untuk mencegah hiperpigmentasi kulit. Kelemahan utama dari agen depigmentasi yang kini beredar di pasaran adalah tingginya faktor risiko yang ditimbulkan akibat pemakaian agen tersebut, sehingga penggunaan dari senyawa tersebut dibatasi dan atau dilarang di beberapa negara. Dengan demikian, penelitian sebelumnya yang telah membuktikan bahwa asam ferulat dan turunannya memiliki aktivitas sebagai inhibitor enzim tirosinase perlu ditelaah lebih lanjut terutama terkait interaksi molekuler yang terjadi antara keduanya.

Struktur makromolekul enzim tirosinase dipilih sebagai reseptor target untuk molekul senyawa asam ferulat dan turunannya. Makromolekul enzim tersebut terlebih dahulu dipreparasi dengan menghilangkan molekul air dan ligan alami yaitu asam kojat, selanjutnya ditambahkan atom hidrogen polar, dan dihitung muatan parsial Kollman dengan menggunakan perangkat lunak MGLTools 1.5.6 yang dilengkapi dengan AutoDock 4.2 [40]. Tahapan preparasi makromolekul enzim bertujuan untuk memastikan agar molekul senyawa uji dapat membentuk interaksi yang stabil dengan bagian sisi aktif makromolekul enzim. Asam kojat yang telah membentuk kompleks dengan enzim tirosinase dapat digunakan sebagai molekul pembanding untuk mengamati interaksi dan afinitas molekul yang paling baik.

Pemodelan dan optimasi molekul senyawa uji menjadi struktur tiga dimensi dilakukan dengan menggunakan perangkat lunak Quantum ESPRESSO v.6.6. Konformasi hasil pemodelan molekul senyawa uji terbaik dipilih berdasarkan energi total hasil optimasi geometri [41]. Energi total yang sudah terintegrasi dalam perangkat lunak Quantum ESPRESSO v.6.6 digunakan untuk menggambarkan konformasi struktur molekul senyawa uji yang dimodelkan sehingga mendekati keadaan aslinya dan diharapkan mampu menghasilkan interaksi yang stabil dengan makromolekul enzim target. Berdasarkan hasil pemodelan molekul senyawa uji yang terdapat pada Tabel 1, dapat diprediksi bahwa asam ferulat dan turunannya akan mampu berinteraksi dengan baik pada area sisi aktif pengikatan enzim tirosinase. Akan tetapi, nilai energi total yang paling baik ditunjukkan oleh senyawa asam isoferulat yaitu sebesar $-0,20982568$ au. Selain itu, senyawa asam iso-ferulat juga menunjukkan stabilitas yang baik pada studi farmakokinetika dibandingkan dengan senyawa asam kafeat dan asam ferulat, dengan nilai 98,3\% [42].

Selanjutnya, aktivitas biologis dari setiap senyawa uji diprediksi dengan menggunakan server web PASS prediction. Berdasarkan hasil prediksi yang terdapat pada Tabel 2, dapat diketahui aktivitas biologis yang relevan dengan aktivitas biologis yang sedang diteliti beserta dengan spektrum probabilitasnya. Dua jenis aktivitas biologis yang dianalisis diantaranya adalah aktivitas melanin inhibitor dan tyrosine 3 bydroxylase inhibitor (penghambat enzim tirosinase). Seluruh senyawa uji pada penelitian ini menunjukkan probabilitas aktif terhadap kedua aktivitas biologis yang ditunjukkan oleh nilai $\mathrm{Pa}>\mathrm{Pi}$. Lebih lanjut lagi, berdasarkan aktivitas sebagai melanin inhibitor, nilai Pa dari seluruh senyawa uji berada pada rentang 0,274 sampai 0,512. Nilai Pa tertinggi ditunjukkan oleh senyawa metil ferulat, kemudian diikuti oleh etil ferulat, asam ferulat, asam iso-ferulat, dan coniferil aldehid. Kemudian berdasarkan analisis aktivitas biologis sebagai tyrosine 3 bydroxylase inhibitor yang merupakan aktivitas spesifik pada penelitian ini, nilai Pa berada pada rentang 0,490 hinga 0,200. Nilai Pa tertinggi diperoleh oleh senyawa metil ferulat, kemudian diikuti oleh asam ferulat, asam isoferulat, etil ferulat, dan coniferil aldehid.

Makromolekul enzim tirosinase yang telah dipreparasi kemudian diidentifikasi dan dievaluasi pada bagian sisi aktifnya dengan menggunakan perangkat lunak BIOVIA Discovery Studio 2020 sehingga sifat dan karakteristik dari area pengikatan pada enzim tirosinase dapat diketahui secara detail. Seperti yang ditunjukkan pada Gambar 3, interaksi molekuler yang terjadi antara enzim tirosinase dengan asam kojat terdiri dari 4 ikatan hidrogen (dengan His192, His377, Thr391, dan Ser394) dan 1 interaksi hidrofobik (dengan His381). Berdasarkan hasil pengamatan tersebut maka dapat diprediksi bahwa residu asam amino tersebut berperan sebagai komponen penyusun dari sisi aktif pengikatan makromolekul enzim tirosinase. Kemudian juga dilakukan validasi metode penambatan molekuler untuk asam kojat yang bertindak sebagai ligan 


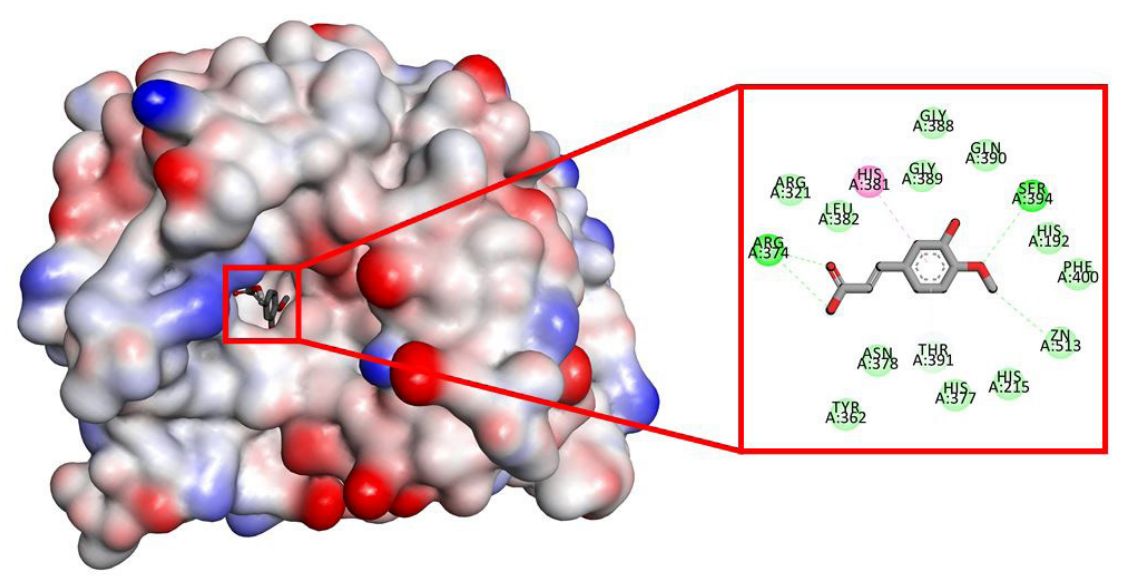

Gambar 4. Interaksi molekuler antara makromolekul enzim tirosinase dengan molekul senyawa asam iso-ferulat

alami. Nilai RMSD yang diperoleh dari tahapan validasi metode ini menunjukkan nilai sebesar $0,78 \AA$. Dengan demikian parameter hasil validasi metode dapat digunakan pada tahap simulasi penambatan molekuler berupa grid box yang berukuran $64 \times 60 \times 60$ dan grid center pada koordinat $\mathrm{X}=-31,471 ; \mathrm{Y}=-3,61 ; \mathrm{Z}=-24,849$.

Simulasi penambatan molekuler dilakukan dengan menggunakan perangkat lunak MGLTools 1.5.6 yang dilengkapi dengan AutoDock 4.2 untuk mengamati afinitas paling baik diantara kelima molekul senyawa uji, serta mengidentifikasi dan mengevaluasi interaksi molekuler yang terjadi terhadap makromolekul enzim tirosinase. Model pengikatan ligan-reseptor dengan konformasi terbaik hasil penambatan molekuler dipilih dan dibandingkan berdasarkan nilai energi bebas ikatan [43]. Berdasarkan data hasil penambatan molekuler yang terdapat pada Tabel 3, menunjukkan bahwa molekul senyawa asam iso-ferulat memiliki afinitas yang paling baik, yaitu dengan nilai energi bebas ikatan $-25,06 \mathrm{~kJ} / \mathrm{mol}$. Jika dibandingkan dengan lokasi pengikatan asam kojat, fenomena tersebut membuktikan bahwa lokasi tempat pengikatan senyawa asam iso-ferulat tidak jauh berbeda dengan asam kojat [44]. Kemudian asam iso-ferulat juga menunjukkan aktivitas inhibitor kompetitif terhadap monofenolase dan difenolase dari tirosinase jamur dengan laju reaksi maksimum (vm) dan konstanta inhibisi (KI) masing-masing sebesar $64,5 \mathrm{M} /$ menit dan $0,11 \mathrm{mmol} / \mathrm{L}$ [45,46]. Dengan demikian, dapat diprediksi bahwa senyawa asam iso-ferulat merupakan inhibitor kompetitif dari makromolekul enzim tirosinase.

Identifikasi dan evaluasi lebih lanjut dilakukan terhadap visualisasi dari kompleks molekul senyawa asam iso-ferulat dan makromolekul enzim tirosinase. Seperti yang ditunjukkan pada Gambar 4, dapat diamati bahwa senyawa asam iso-ferulat memiliki kemiripan posisi pengikatan dengan asam kojat. Kemudian apabila dieksplorasi berdasarkan interaksi molekuler yang terbentuk, senyawa tersebut memiliki ikatan yang lebih banyak dibandingkan senyawa uji lain. Interaksi yang terbentuk dari kompleks senyawa asam iso-ferulat dan enzim tirosinase meliputi 3 ikatan hidrogen (dengan Arg374 dan Ser394) dan 1 interaksi hidrofobik (dengan His 381). Ikatan hidrogen merupakan interaksi spesifik yang berperan penting dalam proses interaksi ligan-reseptor. Di

Tabel 4. Prediksi profil adsorpsi, distribusi, metabolisme, dan ekskresi (ADME)

\begin{tabular}{cccc}
\hline Senyawa Uji & Drug-likeness Lipinski & Absorpsi Gastrointestinal & Kelarutan \\
\hline Asam ferulat & Memenuhi & Tinggi & Larut \\
Asam iso-ferulat & Memenuhi & Tinggi & Larut \\
Coniferil aldehid & Memenuhi & Tinggi & Larut \\
Metil ferulat & Memenuhi & Tinggi & Larut \\
\hline
\end{tabular}


(a)

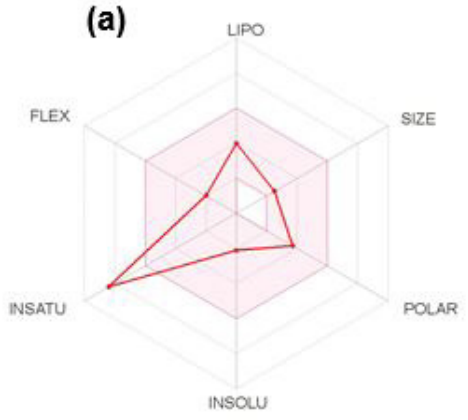

(c)

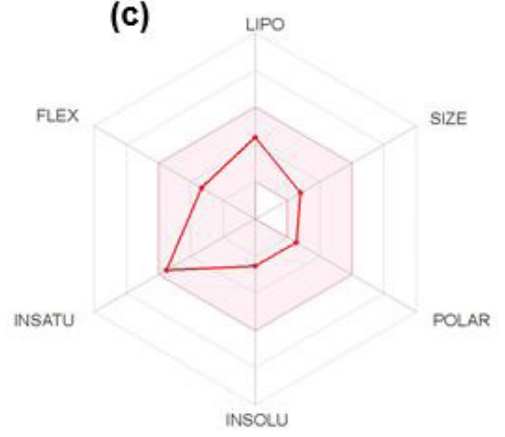

(b)

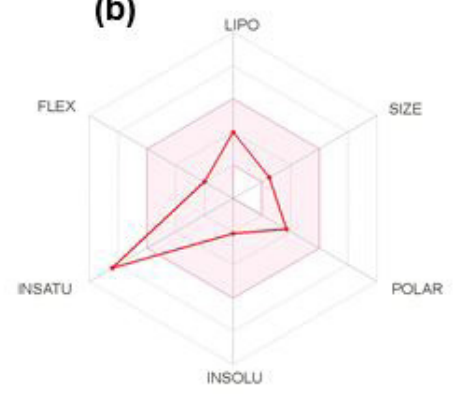

(d)

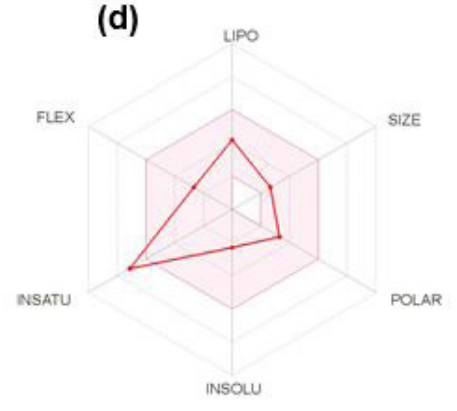

(e)

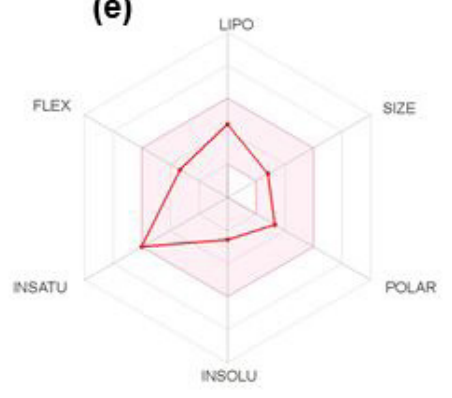

Gambar 5. Radar prediksi profil ADME dari senyawa (a) asam ferulat, (b) asam iso-ferulat, (c) coniferil aldehid, (d) metil ferulat, dan (e) etil ferulat

samping itu, ikatan hidrogen juga berkontribusi terhadap afinitas suatu molekul terhadap protein target [47].

Menariknya, selain 4 interaksi diatas, senyawa ini juga memiliki 1 ikatan dengan logam seng ( $\mathrm{Zn}$ ) yang terdapat pada bagian sisi aktif dari makromolekul enzim tirosinase. Berdasarkan hal tersebut, maka senyawa asam iso-ferulat tidak hanya berpotensi sebagai inhibitor kompetitif, namun juga memiliki potensi sebagai inhibitor non-kompetitif dari enzim tirosinase, dalam hal ini sebagai antioksidan, terkait dengan kemampuannya untuk berikatan dengan logam [48]. Adanya karakteristik inhibitor non-kompetitif dari senyawa tersebut mampu meningkatkan afinitas kompleks ligan-reseptor [49].

Kemudian dilakukan prediksi profil ADME dari setiap senyawa uji sehingga dapat ditentukan mode penghantaran setiap senyawa uji apabila diformulasikan sebagai obat. Tabel 4 menunjukkan profil Drug-likeness Lipinski, absorpsi gastrointestinal, dan kelarutan. Ketiga kriteria tersebut merupakan kriteria yang menggambarkan bioavailabilitas obat apabila diadministrasikan sebagai obat oral. Terlihat bahwa kelima senyawa memenuhi seluruh kriteria sebagai obat oral yang baik. Selanjutnya, sebagai tambahan, radar profil ADME ditampilkan pada penelitian ini (Gambar 5). Pada radar terdapat 6 prediksi parameter ADME yang berkaitan erat dengan biovailabilitas oral suatu senyawa, antara lain LIPO (lipofilitas), SIZE (ukuran), POLAR (polaritas), INSOLU (insolubilitas), INSATU (insaturasi), dan FLEX (fleksibilitas). Zona berwarna merupakan area fisikokimia yang sesuai untuk bioavailabilitas oral. Berdasarkan analisis radar, senyawa metil ferulat, asam ferulat, dan asam iso-ferulat tidak memenuhi salah satu kriteria yaitu insaturasi. Parameter insaturasi dinilai dari fraksi karbon terhibridisasi Sp3 (CSp3) yang tidak boleh kurang dari 0,25 , sedangkan senyawa etil ferulat dan 
Tabel 5. Energi bebas ikatan selama simulasi dinamika molekuler

\begin{tabular}{cccccc}
\hline Senyawa Uji & $\boldsymbol{\Delta E v d w}(\mathbf{k J} / \mathbf{m o l})$ & $\Delta$ Eele (kJ/mol) & $\Delta$ GPB (kJ/mol) & $\Delta$ GNP (kJ/mol) & $\Delta$ GBind (kJ/mol) \\
\hline Asam ferulat & $-76,26$ & $-55,71$ & 114,22 & $-10,35$ & $-28,10$ \\
Asam iso-ferulat & $-109,57$ & $-35,55$ & 124,76 & $-12,70$ & $-33,06$ \\
Coniferil aldehid & $-96,80$ & 15,06 & 39,94 & $-10,80$ & $-52,60$ \\
Metil ferulat & $-90,88$ & $-12,02$ & 85,42 & $-10,65$ & $-28,13$ \\
Etil ferulat & $-94,64$ & $-17,32$ & 60,73 & $-11,06$ & $-62,30$ \\
\hline
\end{tabular}

Keterangan : $\Delta \mathrm{E}_{\mathrm{vdw}}=$ van der Waals contribution, $\Delta \mathrm{E}_{\mathrm{ele}}=$ electrostatic contribution, $\Delta \mathrm{G}_{\mathrm{PB}}=$ polar contribution of desolvation, $\Delta \mathrm{G}_{\mathrm{NP}}=$ non-polar contribution of desolvation

coniferil aldehid memenuhi seluruh kriteri dalam radar ADME.

Tahapan terakhir dilakukan simulasi dinamika molekuler yang bertujuan untuk mengidentifikasi stabilitas interaksi molekuler setiap sistem kompleks selama 200ns dengan menggunakan konformasi awal hasil simulasi penambatan molekuler. Berdasarkan snapshot yang diambil pada awal simulasi (0ns), 50ns, 100ns, 150ns, dan pada akhir simulasi (200ns), dapat diamati bahwa perubahan konformasi senyawa asam ferulat dan turunannya secara umum terjadi ketika simulasi telah mencapai 50ns ( $\underline{\text { Gambar }}$ 6). Posisi keseluruhan senyawa berotasi dan bertranslasi selama simulasi berlangsung, namun perubahan signifikan ditunjukkan oleh senyawa etil ferulat. Senyawa tersebut bergerak fluktuatif dan mulai menjauh dari area situs aktif pengikatan makromolekul enzim tirosinase.
Dinamika interaksi antara senyawa asam ferulat dan turunannya dengan makromolekul target dipelajari menggunakan simulasi dinamika molekuler di dalam pelarut eksplisit. Afinitas yang kuat cenderung mengurangi pergerakan atom yang terikat dan umumnya akan menstabilkan bagian sisi aktif makromolekul enzim tirosinase. Fenomena ini dapat dianalisis dengan menghitung nilai RMSD dari makromolekul target selama simulasi 200ns untuk memastikan stabilitas dan rasionalitas konformasi yang dipilih [50]. Grafik RMSD pada Gambar 7 menunjukkan bahwa senyawa etil ferulat mengalami fluktuasi yang signifikan selama simulasi berlangsung, dengan nilai RMSD rata-rata sebesar 1,84 A. Grafik RMSF juga memperlihatkan adanya kesamaan hasil dengan grafik RMSD, nilai RMSF rata-rata senyawa etil ferulat menunjukkan ketidakstabilan, dengan nilai rata-
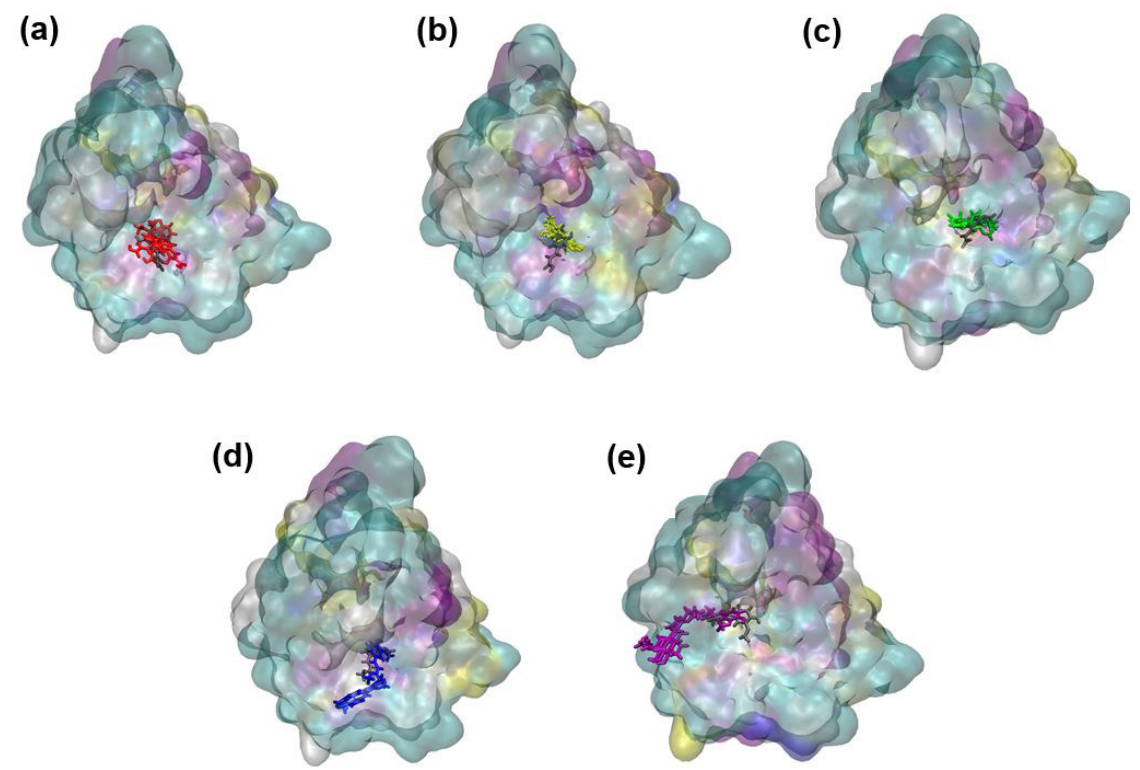

Gambar 6. Visualisasi trajektori senyawa (a) asam ferulat, (b) asam iso-ferulat, (c) coniferil aldehid, (d) metil ferulat, dan (e) etil ferulat selama simulasi dinamika molekuler 

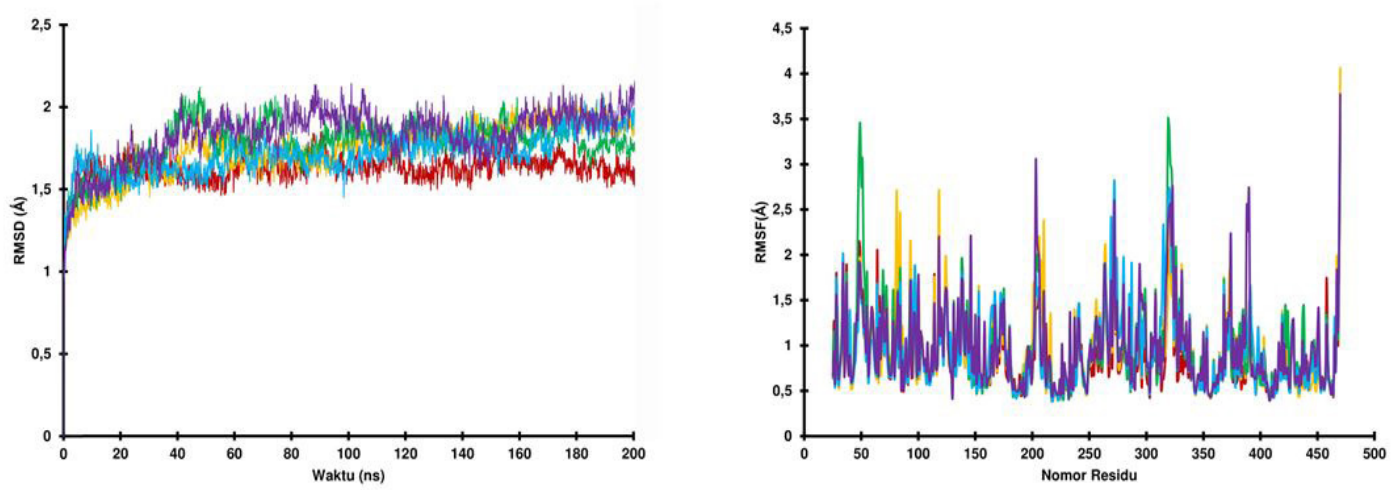

Gambar 7. Grafik RMSD dan RMSF sistem kompleks senyawa asam ferulat (merah), asam iso-ferulat (kuning), coniferil aldehid (hijau), metil ferulat (biru), dan etil ferulat (ungu) terhadap makromolekul enzim tirosinase

rata sebesar $0,98 \AA$. Akan tetapi, secara keseluruhan sistem kompleks memiliki kemampuan untuk mengikat secara kuat dengan residu asam amino pada situs aktif pengikatan makromolekul enzim tirosinase (His192, His377, His381, Thr391, dan Ser394).

Selanjutnya, dilakukan identifikasi terhadap radius of gyration $(\mathrm{Rg})$ untuk menentukan stabilitas kompleks, apakah sistem kompleks stabil dalam bentuk terlipat atau tidak terlipat selama simulasi. Selain itu, pengamatan terhadap solvent-accessible surface area (SASA) juga dilakukan untuk memprediksi sejauh mana makromolekul enzim tirosinase mengalami perubahan konformasi selama simulasi yang dapat diakses oleh molekul air. Kemudian evaluasi dilakukan terhadap adanya pengaruh masingmasing variasi parameter terhadap kerapatan atom atau probabilitasnya pada radius tertentu dengan menggunakan radial distribution factor (RDF) dan analisis stabilitas ikatan hidrogen (H-bond) selama simulasi dinamika molekuler [51].

Nilai $\operatorname{Rg}$ menunjukkan bahwa tidak ada perbedaan yang signifikan dari keseluruhan sistem yang kompleks. Akan tetapi, senyawa etil ferulat memiliki nilai $\mathrm{Rg}$ ratarata yang lebih tinggi dibandingkan dengan senyawa lain yaitu sebesar 2,16 nm. Kemudian hasil dari analisis SASA menunjukkan bahwa senyawa metil ferulat dan etil ferulat memiliki nilai yang cukup tinggi, masing-masing sebesar

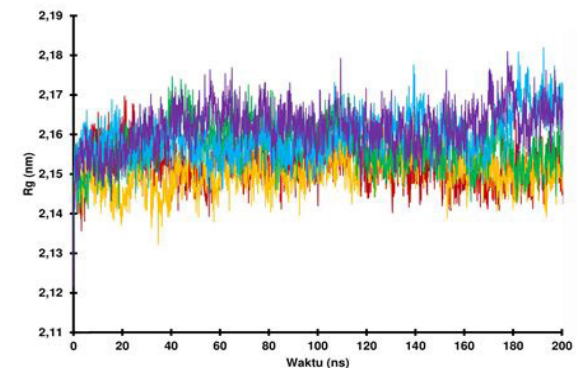

Radius of Gyration (Rg)

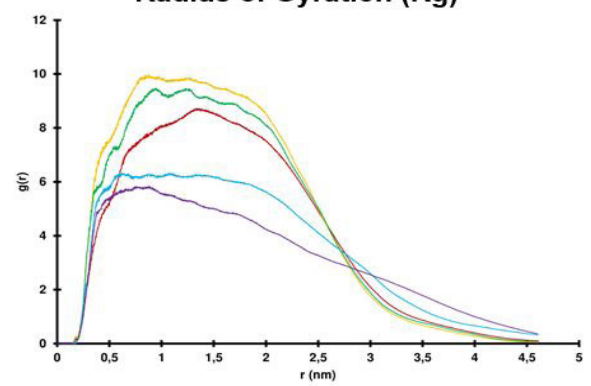

Radial Distribution Factor (RDF)

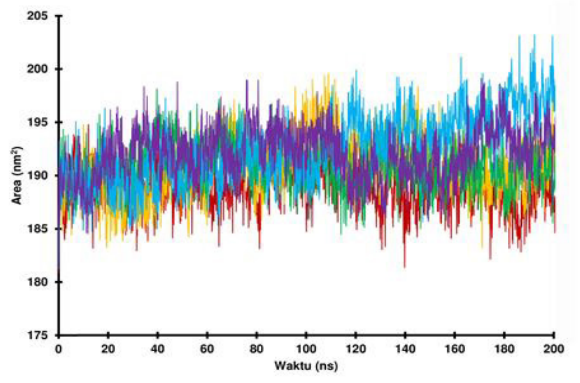

Solvent-Accessible Surface Area (SASA)

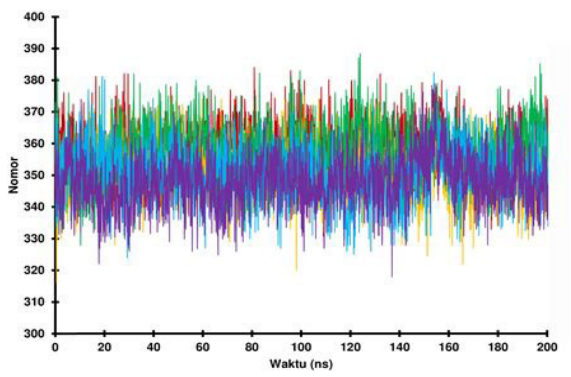

Ikatan Hidrogen (H-Bond)

Gambar 8. Grafik Rg, SASA, RDF, dan H-Bond sistem kompleks senyawa asam ferulat (merah), asam iso-ferulat (kuning), coniferil aldehid (hijau), metil ferulat (biru), dan etil ferulat (ungu) terhadap makromolekul enzim tirosinase 
192,68 $\mathrm{nm}^{2}$ dan 192,05 $\mathrm{nm}^{2}$. Selanjutnya berdasarkan grafik RDF pada Gambar 8, senyawa etil ferulat menunjukkan ketidakteraturan sistem kompleks karena memiliki nilai rata-rata yang rendah, yaitu sebesar 3,12 g(r). Ketiga data tersebut diperkuat dengan hasil perhitungan H-Bond selama simulasi berlangsung yang menunjukkan fluktuasi terjadi di sekitar residu asam amino yang terletak pada situs aktif pengikatan makromolekul enzim tirosinase. Berdasarkan identifikasi yang telah dilakukan dapat diprediksi bahwa senyawa etil ferulat memiliki stabilitas yang kurang baik apabila dibandingkan dengan senyawa turunan asam ferulat lain. Dengan adanya penambahan gugus metil, etil, n-propil, tert-butil, dan n-setil atau selinat menyebabkan senyawa bertindak sebagai aktivator enzim tirosinase. Sementara, gugus n-butil, iso-propil, sek-butil, n-pentil, n-heksil dan n-oktil orselinat mampu meningkatkan konstanta inhibisi sebesar $0,50 \mathrm{mM}$ hingga $0,99 \mathrm{mM}$ [52].

Terakhir dilakukan perhitungan energi bebas ikatan dengan menggunakan metode Molecular Mechanics PoissonBoltzmann Surface Area (MM/PBSA) terhadap beberapa trajektori yang dipilih dari hasil simulasi dinamika molekuler. Berdasarkan hasil perhitungan MM/PBSA senyawa asam ferulat dan turunannya memiliki afinitas yang baik. Namun, afinitas tertinggi dimiliki oleh senyawa etil ferulat, coniferil aldehid, dan asam iso-ferulat dengan nilai energi bebas ikatan masing-masing sebesar $-62,30 \mathrm{~kJ} /$ mol; -52,60 kJ/mol; dan $-33,06 \mathrm{~kJ} / \mathrm{mol}$. Secara umum, energi yang berkontribusi paling besar selama simulasi adalah interaksi van der Waals, interaksi elektrostatik, dan interaksi non-polar. Fenomena ini karena pendekatan $\mathrm{MM} / \mathrm{PBSA}$ memungkinkan pengamatan pengaruh van der Waals dan kontribusi elektrostatik serta perubahan afinitas ligan reseptor yang dipengaruhi oleh proses solvasi pada sistem kompleks [53].

\section{Kesimpulan}

Molekul senyawa bioaktif asam iso-ferulat yang berasal dari kulit buah nanas (Ananas comosus) telah terbukti mampu menghambat enzim tirosinase melalui identifikasi dan evaluasi terhadap interaksi molekuler yang terjadi dengan menggunakan metode penambatan dan dinamika molekuler secara in silico. Berdasarkan hasil penelitian yang telah dilakukan diperoleh bahwa senyawa asam iso-ferulat memiliki afinitas yang paling baik terhadap makromolekul enzim tirosinase yaitu dengan nilai energi bebas ikatan $-25,06 \mathrm{~kJ} / \mathrm{mol}$. Di samping itu, senyawa ini juga memiliki interaksi dengan logam seng ( $\mathrm{Zn}$ ) yang terdapat pada sisi aktif pengikatan enzim tirosinase. Menariknya, senyawa asam iso-ferulat juga memiliki stabilitas yang baik selama simulasi dinamika molekuler. Dengan demikian, senyawa asam iso-ferulat memiliki potensi sebagai kandidat inhibitor kompetitif dan non-kompetitif dari enzim tirosinase untuk pengembangan agen depigmentasi alami.

\section{Referensi}

[1]. Ding HY, Chang TS, Shen HC, Tai SSK. Murine tyrosinase Inhibitors from Cynanchum bungei and evaluation of in vitro and in vivo depigmenting activity. Exp Dermatol. 2011;20(9). https://doi. org/10.1111/j.1600-0625.2011.01302.x

[2]. Nicolaidou E, Katsambas AD. Pigmentation disorders: Hyperpigmentation and hypopigmentation. Vol. 32, Clinics in Dermatology. 2014. https://doi.org/10.1016/j. clindermatol.2013.05.026

[3]. Fistarol SK, Itin PH. Disorders of pigmentation. Vol. 8, JDDG Journal of the German Society of Dermatology. 2010. https://doi. org/10.1111/j.1610-0387.2009.07137.x

[4]. Urasaki MBM. Skin physiological alterations perceived by pregnant women attended at public health services. ACTA Paul Enferm. 2010;23(4). https://doi.org/10.1590/s0103-21002010000400012

[5]. Costa A, Moisés TA, Cordero T, Alves CRT, Marmirori J. Associação de emblica, licorice e belides como alternativa à hidroquinona no tratamento clínico do melasma. An Bras Dermatol. 2010;85(5). https://doi.org/10.1590/s0365-05962010000500003

[6]. Zimmermann Franco DC, De Carvalho GSG, Rocha PR, Da Silva Teixeira R, Da Silva AD, Barbosa Raposo NR. Inhibitory effects of resveratrol analogs on mushroom tyrosinase activity. Molecules. 2012;17(10). https://doi.org/10.3390/molecules171011816

[7]. Bernard P, Berthon JY. Resveratrol: An original mechanism on tyrosinase inhibition. Int J Cosmet Sci. 2000;22(3). https://doi. org/10.1046/j.1467-2494.2000.00019.x

[8]. Baurin N, Arnoult E, Scior T, Do QT, Bernard P. Preliminary screening of some tropical plants for anti-tyrosinase activity. J Ethnopharmacol. 2002;82(2-3). https://doi.org/10.1016/S0378-8741(02)00174-5

[9]. Adhikari A, Devkota HP, Takano A, Masuda K, Nakane T, Basnet P, et al. Screening of Nepalese crude drugs traditionally used to treat hyperpigmentation: In vitro tyrosinase inhibition. Int J Cosmet Sci. 2008;30(5). https://doi.org/10.1111/j.1468-2494.2008.00463.x

[10]. Macrini DJ, Suffredini IB, Varella AD, Younes RN, Ohara MT. Extracts from Amazonian plants have inhibitory activity against tyrosinase: An in vitro evaluation. Brazilian J Pharm Sci. 2009;45(4). https://doi. org/10.1590/S1984-82502009000400015

[11]. Chodurek E, Orchel A, Orchel J, Kurkiewicz S, Gawlik N, Dzierzewicz $Z$, et al. Evaluation of melanogenesis in A-375 cells in the presence of DMSO and analysis of pyrolytic profile of isolated melanin. Sci World J. 2012;2012. https://doi.org/10.1100/2012/854096

[12]. Lin YS, Chen SH, Huang WJ, Chen CH, Chien MY, Lin SY, et al. Effects of nicotinic acid derivatives on tyrosinase inhibitory and antioxidant activities. In: Food Chemistry. 2012. https://doi.org/10.1016/j. foodchem.2011.12.052

[13]. Lin YS, Chuang M Te, Chen CH, Chien MY, Hou WC. Nicotinic acid hydroxamate downregulated the melanin synthesis and tyrosinase activity through activating the MEK/ERK and AKT/GSK3 $\beta$ signaling pathways. J Agric Food Chem. 2012;60(19). https://doi. org/10.1021/if301109p

[14]. Parvez S, Kang M, Chung HS, Cho C, Hong MC, Shin MK, et al. Survey and mechanism of skin depigmenting and lightening agents. Vol. 20, Phytotherapy Research. 2006. https://doi.org/10.1002/ptr.1954

[15]. Naqvi F, - Z, Imran I, Khan Faraz AA, Tabussam T, Sikandar S. A double blind study to compare the efficacy of Aloe vera gel and undecylenoyl phenylalanine $2 \%$ for treatment of melisma. Prof Med J. 2020;27(08). https://doi.org/10.29309/tpmi/2020.27.08.4459

[16]. Nigam P. Adverse reactions to cosmetics and methods of testing Vol. 75, Indian Journal of Dermatology, Venereology and Leprology. 2009. https://doi.org/10.4103/0378-6323.45214 
[17]. Sheth VM, Pandya AG. Melasma: A comprehensive update: Part II. Vol. 65, Journal of the American Academy of Dermatology. 2011. https://doi.org/10.1016/j.jaad.2011.06.001

[18]. Zhu W, Gao J. The use of botanical extracts as topical skin-lightening agents for the improvement of skin pigmentation disorders. In: Journal of Investigative Dermatology Symposium Proceedings. 2008. https://doi.org/10.1038/jidsymp.2008.8

[19]. Cerqueira FM, De Medeiros MHG, Augusto O. Antioxidantes dietéticos: Controvérsias e perspectivas. Vol. 30, Quimica Nova. 2007. https://doi.org/10.1590/S0100-40422007000200036

[20]. Zhao Z, Moghadasian MH. Chemistry, natural sources, dietary intake and pharmacokinetic properties of ferulic acid: A review. Vol. 109, Food Chemistry. 2008. https://doi.org/10.1016/i. foodchem.2008.02.039

[21]. Mancuso C, Santangelo R. Ferulic acid: Pharmacological and toxicological aspects. Vol. 65, Food and Chemical Toxicology. 2014. https://doi.org/10.1016/i.fct.2013.12.024

[22]. Nazaré AC, De Faria CMQG, Chiari BG, Petrônio MS, Regasini LO, Silva DHS, et al. Ethyl ferulate, a component with anti-inflammatory properties for emulsion-based creams. Molecules. 2014;19(6). https://doi.org/10.3390/molecules19068124

[23]. Saija A, Tomaino A, Trombetta D, De Pasquale A, Uccella N, Barbuzzi $T$, et al. In vitro and in vivo evaluation of caffeic and ferulic acids as topical photoprotective agents. Int J Pharm. 2000;199(1). https:// doi.org/10.1016/S0378-5173(00)00358-6

[24]. Kumar N, Pruthi V. Potential applications of ferulic acid from natural sources. Vol. 4, Biotechnology Reports. 2014. https://doi. org/10.1016/j.btre.2014.09.002

[25]. Lai X, Wichers HJ, Soler-Lopez M, Dijkstra BW. Structure of Human Tyrosinase Related Protein 1 Reveals a Binuclear Zinc Active Site Important for Melanogenesis. Angew Chemie. 2017;129(33). https://doi.org/10.1002/ange.201704616

[26]. Karamac M, Koleva L, Kancheva VD, Amarowicz R. The structureantioxidant activity relationship of ferulates. Molecules. 2017;22(4). https://doi.org/10.3390/molecules22040527

[27]. Kurniawan F, Miura Y, Kartasasmita RE, Mutalib A, Yoshioka N, Tjahjono DH. In silico study, synthesis, and cytotoxic activities of porphyrin derivatives. Pharmaceuticals. 2018;11(1). https://doi. org/10.3390/ph11010008

[28]. Giannozzi P, Baroni S, Bonini N, Calandra M, Car R, Cavazzoni C, et al. QUANTUM ESPRESSO: A modular and open-source software project for quantum simulations of materials. J Phys Condens Matter. 2009;21(39). https://doi.org/10.1088/0953-8984/21/39/395502

[29]. Lagunin A, Stepanchikova A, Filimonov D, Poroikov V. PASS: Prediction of activity spectra for biologically active substances. Bioinformatics. 2000;16(8). https://doi.org/10.1093/bioinformatics/16.8.747

[30]. Ramadhan DSF, Fakih TM, Arfan A. Activity Prediction of Bioactive Compounds Contained in Etlingera elatior Against the SARS-CoV-2 Main Protease: An In Silico Approach. Borneo J Pharm. 2020;3(4). https://doi.org/10.33084/bjop.v3i4.1634

[31]. Anzali S, Barnickel G, Cezanne B, Krug M, Filimonov D, Poroikov V. Discriminating between drugs and nondrugs by prediction of activity spectra for substances (PASS). J Med Chem. 2001;44(15). https:// doi.org/10.1021/jm0010670

[32]. Kemmish H, Fasnacht M, Yan L. Fully automated antibody structure prediction using BIOVIA tools: Validation study. PLOS One. 2017;12(5). https://doi.org/10.1371/journal.pone.0177923

[33]. Hassan NM, Alhossary AA, Mu Y, Kwoh CK. Protein-Ligand Blind Docking Using QuickVina-W with Inter-Process Spatio-Temporal Integration. Sci Rep. 2017;7(1). https://doi.org/10.1038/s41598017-15571-7

[34]. Morris GM, Ruth H, Lindstrom W, Sanner MF, Belew RK, Goodsell DS, et al. Software news and updates AutoDock4 and AutoDockTools4: Automated docking with selective receptor flexibility. J Comput Chem. 2009; https://doi.org/10.1002/jcc.21256

[35]. Pantsar T, Poso A. Binding affinity via docking: Fact and fiction. Vol. 23, Molecules. 2018. https://doi.org/10.3390/molecules23081899
[36]. Daina A, Michielin O, Zoete V. SwissADME: A free web tool to evaluate pharmacokinetics, drug-likeness and medicinal chemistry friendliness of small molecules. Sci Rep. 2017;7. https://doi. org/10.1038/srep42717

[37]. Man VH, He X, Derreumaux P, Ji B, Xie XQ, Nguyen PH, et al. Effects of All-Atom Molecular Mechanics Force Fields on Amyloid Peptide Assembly: The Case of A $\beta$ 16-22 Dimer. J Chem Theory Comput. 2019; https://doi.org/10.1021/acs.jctc.8b01107

[38]. Bernardi A, Faller R, Reith D, Kirschner KN. ACPYPE update for nonuniform 1-4 scale factors: Conversion of the GLYCAM06 force field from AMBER to GROMACS. SoftwareX. 2019;10. https://doi. org/10.1016/j.softx.2019.100241

[39]. Ahmad S, Abbasi HW, Shahid S, Gul S, Abbasi SW. Molecular docking, simulation and MM-PBSA studies of nigella sativa compounds: a computational quest to identify potential natural antiviral for COVID-19 treatment. J Biomol Struct Dyn. 2020; https://doi.org/1 $\underline{0.1080 / 07391102.2020 .1775129}$

[40]. Fakih TM, Arumsari A, Dewi ML, Hazar N, Syarza TM. Identifikasi Mekanisme Molekuler Senyawa Ftalosianina sebagai Kandidat Photosensitizer pada Terapi Fotodinamika secara In Silico. ALCHEMY J Penelit Kim. 2021;17(1). https://doi.org/10.20961/ alchemy.17.1.41184.37-42

[41]. Mohammad RK, Madlol RA, Umran NM, Sharrad FI. Structure and electronic properties of substitutionally doped Cycloheptane molecule using DFT. Results Phys. 2016;6. https://doi.org/10.1016/j. rinp.2016.11.039

[42]. Wang LH, Hsu KY, Hsu FL, Lin SJ. Simultaneous determination of caffeic acid, ferulic acid and isoferulic acid in rabbit plasma by high performance liquid chromatography. J Food Drug Anal. 2008;16(1). https://doi.org/10.38212/2224-6614.2382

[43]. Darusman F, Fakih TM. Studi Interaksi Senyawa Turunan Saponin dari Daun Bidara Arab (Ziziphus spina-christi L.) sebagai Antiseptik Alami secara In Silico. J Sains Farm Klin. 2020;7(3). https://doi. org/10.25077/isfk.7.3.233-239.2020

[44]. Veeraragavan V, Radhakrishnan N, Chidambaram R. Predicting the biodegradability nature of imidazole and its derivatives by modulating two histidine degradation enzymes (urocanase and formiminoglutamase) activities. Asian J Pharm Clin Res. 2017;10(11) https://doi.org/10.22159/ajpcr.2017.v10i11.20999

[45]. Lien CY, Chen CY, Lai ST, Chan CF. Kinetics of mushroom tyrosinase and melanogenesis inhibition by $\mathrm{N}$-acetyl-pentapeptides. Sci World J. 2014;2014. https://doi.org/10.1155/2014/409783

[46]. Huang W-Y, Chen H-J, Lin C-C, Chen C-S, Lin Y-S. Kinetics Investigation on Mushroom Tyrosinase Inhibition of Proso Millet. J Chem. 2018;2018. https://doi.org/10.1155/2018/2387926

[47]. Chopra N, Kaur D, Chopra G. Nature and Hierarchy of HydrogenBonding Interactions in Binary Complexes of Azoles with Water and Hydrogen Peroxide. ACS Omega. 2018;3(10). https://doi. org/10.1021/acsomega.8b01523

[48]. Norel R, Sheinerman F, Petrey D, Honig B. Electrostatic contributions to protein-protein interactions: Fast energetic filters for docking and their physical basis. Protein Sci. 2008;10(11). https://doi. org/10.1110/ps.12901

[49]. Choi I, Park Y, Ryu IY, Jung HJ, Ullah S, Choi H, et al. In silico and in vitro insights into tyrosinase inhibitors with a 2-thioxooxazoline-4one template. Comput Struct Biotechnol J. 2021;19. https://doi. org/10.1016/j.csbj.2020.12.001

[50]. Pandey B, Grover A, Sharma P. Molecular dynamics simulations revealed structural differences among WRKY domain-DNA interaction in barley (Hordeum vulgare). BMC Genomics. 2018;19(1) https://doi.org/10.1186/s12864-018-4506-3

[51]. Pitaloka DAE, Ramadhan DSF, Arfan, Chaidir L, Fakih TM. Docking based virtual screening and molecular dynamics simulations of quercetin analogs as enoyl-acyl carrier protein reductase (Inha) inhibitors of mycobacterium tuberculosis. Sci Pharm. 2021;89(2). https://doi.org/10.3390/scipharm89020020 
[52]. Zolghadri S, Bahrami A, Hassan Khan MT, Munoz-Munoz J, GarciaMolina F, Garcia-Canovas F, et al. A comprehensive review on tyrosinase inhibitors. Vol. 34, Journal of Enzyme Inhibition and Medicinal Chemistry. 2019. https://doi.org/10.1080/14756366.20 18.1545767
[53]. Sk MF, Roy R, Jonniya NA, Poddar S, Kar P. Elucidating biophysical basis of binding of inhibitors to SARS-CoV-2 main protease by using molecular dynamics simulations and free energy calculations. J Biomol Struct Dyn. 2021;39(10). https://doi.org/10.1080/073911 02.2020 .1768149 material for any purpose, even commercially) under the following terms: Attribution - You must give appropriate credit, provide a link to the license, and indicate 